\title{
Is the future of electoral reform local?
}

\author{
Article
}

Accepted Version

Renwick, A. (2014) Is the future of electoral reform local? The Political Quarterly, 85 (3). pp. 368-372. ISSN 1467-923X doi: https://doi.org/10.1111/1467-923X.12105 Available at https://centaur.reading.ac.uk/38058/

It is advisable to refer to the publisher's version if you intend to cite from the work. See Guidance on citing.

Published version at: http://onlinelibrary.wiley.com/doi/10.1111/1467-923X.12105/abstract

To link to this article DOI: http://dx.doi.org/10.1111/1467-923X.12105

Publisher: Blackwell

Publisher statement: The definitive version is available at wileyonlinelibrary.com

All outputs in CentAUR are protected by Intellectual Property Rights law, including copyright law. Copyright and IPR is retained by the creators or other copyright holders. Terms and conditions for use of this material are defined in the End User Agreement.

\section{www.reading.ac.uk/centaur}

\section{CentAUR}

Central Archive at the University of Reading

Reading's research outputs online 


\section{Is the Future of Electoral Reform Local?}

ALAN RENWICK

The Electoral Reform Society has recently published two reports putting the case for electoral reform in local government. These suggest acceptance, in the wake of defeat in the 2011 Alternative Vote referendum, that the group's ultimate goal of change to the Westminster electoral system is unlikely to be fulfilled soon and that a more gradual strategy is therefore needed. This paper examines this shift by asking three questions. First, is Westminster electoral reform really a dead letter? Second, is local electoral reform more likely—and, if so, just how much more likely? Third, would local electoral reform matter in itself?

Keywords electoral reform, local elections, single transferable vote, STV, Labour, Conservatives

The Electoral Reform Society has recently published two reports putting the case for electoral reform in local government in England and Wales. Rather than presenting an abstract, theoretical case, they speak to explicitly partisan perspectives: the first report, published in late 2013, argues that a system of proportional representation (PR) at local level would help the Conservatives, while the second, which followed in 2014, contends that local PR would also be in the interests of Labour. ${ }^{1}$

Both reports advocate the single transferable vote (STV) form of PR, which is already used for local elections in both Scotland and Northern Ireland. In that sense, the proposals fit the traditions of the Electoral Reform Society ever since its foundation in 1884. In two other 
senses, however, the reports represent something of a departure from previous practice for the world's oldest political reform pressure group. First, the focus on local rather than Westminster elections is new: the Electoral Reform Society has sometimes acted in the past as though anything short of its ultimate goal of Westminster reform was not worth fighting for. Second, the strategic focus on partisan interests is also relatively unfamiliar: the Electoral Reform Society has often campaigned with a certain detachment from the grubby realities of politics, as though putting forward an impeccable intellectual case for reform would be enough to achieve it.

The backdrop, of course, is the failed referendum of 2011 on adopting the alternative vote (AV) system for parliamentary elections, which taught the reform community that achieving change in the UK's core democratic institutions would be even harder than many had supposed. Recognising that major electoral reform at Westminster is off the agenda for the foreseeable future, the Electoral Reform Society has sought to shift the debate to what it hopes is less contentious ground. Reform at the local government level, they calculate, will be easier than at the national level. And if PR can be introduced at this level, it might serve as a bridgehead for wider reform in the years beyond.

This article assesses this change of tactics in four steps. First, it considers whether reformers have drawn the correct inference from the 2011 referendum in concluding that the battle for Westminster electoral reform is currently unwinnable. Second, it assesses whether local electoral reform is any more likely. Third, it pursues in more detail the question of just how likely local electoral reform really is. Finally, it asks what the likely effects would be of introducing PR at the local level.

\section{Is reform of the Westminster electoral system a dead letter?}


These two reports reflect a judgement by the Electoral Reform Society that reform of the first-past-the-post system used to elect the House of Commons is not currently a winnable objective. As I have argued in detail elsewhere, electoral reforms happen through three main routes: top-down pursuit of political interests; bottom-up pressure from the public; and a mixture of the two. ${ }^{2}$ To see whether the Electoral Reform Society is right, we need to consider the viability of each of these routes in the UK today.

The top-down mechanism could work for the Westminster electoral system either if one of the two main parties concluded that a different system would serve its interests better than the status quo or if a smaller party bargained for reform in the context of a hung parliament. The first of these possibilities is not likely to happen any time soon. Labour flirted with electoral reform in the 1990s, when successive electoral defeats eroded the party's self-confidence, but enthusiasm withered as the prospect of majority power returned. The Conservatives maintained unwavering support for first-past-the-post despite three consecutive defeats at the hands of Tony Blair, and their preference at present is to crush rather than accommodate the threat from UKIP. This predilection for sticking it out during hard times should be no surprise. In the short term, parties fear they will look defeatist if they respond to bad polls by proposing a change in the rules. In the medium and long term, they want to return to a position where they can secure majority power. The extreme example is that of the Canadian Progressive Conservatives, who maintained their support for first-pastthe-post even though they held on to just two seats in the 1993 federal election.

The belief that a hung parliament was all that was needed for electoral reform to occur has, meanwhile, been shattered by experience since 2010. This again should not have come as a surprise. The Liberal Democrats and their predecessors have always been wary of bargaining too hard on the electoral reform issue lest they look obsessed with a detail that is irrelevant to most voters and directly affects only their own narrow interests: Jo Grimond 
exercised such caution during talk of possible pacts in 1964; Jeremy Thorpe acted similarly in 1974; and David Steel did not withdraw the Liberals from their pact with Labour in 1977 when the latter failed to deliver PR for the European Parliament. In just the same way, the Liberal Democrats entered government in 2010 with the promise of no more than a referendum on minor electoral tinkering. That referendum has set a precedent: it will be difficult henceforth to enact any significant electoral reform without taking the issue to the people. And - as British politicians know better now than they did in 2010 - referendums are typically very conservative instruments. None of this is much affected by whether the main party in government is Labour or the Conservatives.

The bottom-up route to electoral reform appears equally improbable. This route operates only where voters are angry about the state of politics and convinced that changing the electoral system might go some way to alleviating the source of their anger. But genuine anger about politics — rather than apathy, disillusionment or grumpiness — is rare: most voters pay attention only to what directly affects their daily lives, and the character of the political system does not do so. Only if voters see failures in the political system as leading to policy failures that hit them in their pockets - as they did in Italy, Japan and New Zealand in the early 1990s—-do they mobilise for electoral reform.

The difficulty facing those wanting reform for Westminster is that there is no problem that British voters care about to which electoral reform is a plausible solution. British political discourse typically presumes that single-party government is good government: that hung parliaments risk paralysis in the face of adversity. The current coalition government has gained a reputation for messy compromises that leave a nasty taste: most voters would prefer not to see another hung parliament. ${ }^{3}$ It would thus be hard to convince voters that a change making hung parliaments more likely would be good for governance. 
That leaves only the mixed route to reform. Here, there is no specific public demand for electoral reform, but a general background of public disillusionment with politics motivates politicians to respond by promising changes that they can claim address those sentiments. In the wake of the 2009 MPs' expenses scandal, this mechanism led to promises for a range of reforms, including recall of MPs, open primaries for candidate selection, and revitalisation of parliamentary committees.

But this mechanism cannot satisfy the diehard supporters of electoral reform, for two reasons. First, it leaves the politicians with considerable freedom to choose which reforms to run with, and they will naturally choose those that are least incompatible with their own interests. Select committee reforms came to the fore because backbench politicians wanted a stronger role; recall gained traction among party leaders because only a few, troublesome MPs would ever likely be affected. Electoral reform, by contrast, has few beneficiaries among those in power. Second, even where reforms are promised, they do not always happen. The Conservative policy of funding open primaries made it into the Coalition agreement but progressed no further. ${ }^{4}$ Recall long seemed likely to suffer the same fate, though it might now limp through shortly before the 2015 election. This mechanism is thus too weak to deliver major change to the core of the electoral system.

The conclusion reached by the Electoral Reform Society that PR for Westminster is not currently a realistic goal is therefore well founded. No path to such a change will open in the foreseeable future.

\section{Is local electoral reform more likely?}

So is the Electoral Reform Society also right in calculating that change in the electoral system at the local level is more likely? For three reasons, the answer is 'yes'. 
The first is simply that it is always easier for politicians to change the system for electing a body to which they do not themselves belong. Changing the system by which they are themselves elected affects their career paths, campaigning methods and prospects of holding their seats. Changing another electoral system is unlikely to do any of these things, except indirectly. Thus, the Blair governments were content to introduce new voting systems for the European Parliament, the devolved assemblies and elected mayors, but baulked at the idea of change in Westminster.

The second reason, meanwhile, goes to the heart of the Electoral Reform Society's two reports: while electoral reform at Westminster would not serve the interests of either of the main parties (at least on their own conception of their interests), that is not so obviously true for local electoral reform. Both reports point out that, under first-past-the-post, the Conservatives and Labour parties suffer severe under-representation across large parts of the country: the Conservatives principally in the northern cities; Labour principally in the south. This clearly has negative effects regionally for both parties. It has ramifications beyond local government: without local councillors, the parties lack activists on the ground who could build up support and start to shift patterns of voting in Westminster elections. If, therefore, either party wants to claim to be a national party-if the Conservatives want to go back to winning parliamentary seats in the northern cities and Labour want again to win more than a handful of seats outside London in the south - the argument made in the Electoral Reform Society reports is that changing the local electoral system is a good place to start. It is possible, therefore, that support for local electoral reform will grow within the main parties themselves, potentially putting pressure on the national party leaderships.

There is no doubt that the logic underlying these arguments is correct; indeed, particularly in the Conservative-facing report, it is backed up by detailed numbers. Furthermore, it is not an entirely new argument. The important report of the Hansard 
Society's Commission on Electoral Reform of 1976 observed that first-past-the-post 'underrepresents the major parties in particular areas', and argued that 'a government formed by a major party should not lack the opportunity to include representatives' outside that party's areas of greatest strength. ${ }^{5}$ Even earlier than that, in 1968, the political scientist Alan Cairns argued that Canada's first-past-the-post system exaggerated differences in support for the parties across the provinces and thereby damaged the democratic system. ${ }^{6}$

An obvious counterargument to the claim that PR in local government would therefore serve the parties' interests is that, while PR might help each of the main parties where it is weak, it would, concomitantly, weaken each party where it is strong. The Electoral Reform Society's Labour-facing report does contain at least a partial response to that, arguing that the current system actually harms Labour in its areas of greatest strength. The reasoning is that, where Labour routinely wins vast majorities of the local council seats, it often becomes complacent, leading to bad governance, splits and electoral collapse; recriminations follow, and the party is therefore often slow to recover. Much better, the report contends, would be a healthy degree of contestation all the time. The paper is frank in offering evidence for this pattern.

That argument might not convince all party activists in areas of party strength. But it should ring true to party leaders: we need only recall Neil Kinnock's internal party battles against the Militant tendency in Liverpool and elsewhere in the 1980s to see the troubles that dysfunctional local parties can cause to their national leaderships.

The third and final reason for thinking electoral reform is more likely at the local than the national level is that there is no reason to think it would require a referendum. The precedent set by the 2011 referendum extends only to changes to the Westminster electoral system. The precedent for local electoral reforms is provided by the adoption of PR in 
Scotland in 2004, when enactment followed the normal legislative process. The extra veto opportunity created by a referendum is thus absent.

Overall, then, it is clear that the likelihood of local electoral reform is greater than that of reform at Westminster.

\section{But just how likely?}

Local electoral reform might be more likely than Westminster electoral reform, but that still does not mean that the likelihood is necessarily very high. Just what, then, are the chances that local electoral reform will actually occur?

Despite what was said above, two important barriers must be recognised. One is that, as has been suggested, many local activists would be likely to oppose. In many parts of the country, the adoption of PR would lead to a loss of seats for one or other of the main parties. Even in areas of relative weakness, many sitting councillors, having been elected by one long-familiar method, might baulk at having to learn a different set of rules requiring different modes of behaviour. A proposal for local electoral reform would therefore be divisive within both of the main parties, and so party leaders, whatever their own preferences, might prefer to avoid it.

The second barrier is that many within the main parties are likely to view local electoral reform as the thin end of a wedge: if they allow the principle at local level, they will fear, it will become harder to resist at national level. Indeed, as was noted above, that is precisely the expectation — and hope — of the Electoral Reform Society too, so they will find this a hard argument to counteract. Given that PR has been used now for a decade and a half for European and devolved assembly elections without significant pressure on the 
Westminster system, the strength of such spillover effects is open to doubt. But that there might be some effect is certainly plausible.

Given these considerations, there is no reason to think that either of the main parties will adopt local PR out of pure self-interest. Neither is either party likely to offer it as a sop to disgruntled voters: other reforms are less costly for the politicians and more obviously respond to the gripes that voters have. One or another party might devolve the power to decide the electoral system to local authorities and tout this as a sign of commitment to greater localism. But that would have little practical effect, given that in most areas, most of the time, the parties that might support change will not be in office.

The only plausible scenario, therefore, is that local PR might be adopted as part of a post-election deal in another hung parliament. The Electoral Reform Society's current strategy seems to be directed at two objectives: to bolster the confidence of Liberal Democrats in pushing hard for local electoral reform in such a situation despite their humiliation over national electoral reform in 2011; and to soften up the two main parties toward accepting this demand.

Whether this will succeed for 2015-even if there is a hung parliament - is far from clear. The Liberal Democrats will be very cautious; while manifesto support for STV in local government looks likely, the party's current policy pronouncements give every reason to think this will be low on the list of priorities.

Over the longer term, however, the possibility of local PR looks significant. The idea of electoral reform will lose its current toxicity and the Liberal Democrats will become less fearful of nudging it up their list of priorities. The main parties' electoral deserts will likely remain, so the case for change will continue to build within those parties. In the event of a 
hung parliament in 2020 or 2025, therefore, the chances for local electoral reform look quite reasonable.

\section{Would local electoral reform matter?}

The UK's electoral reformers are right, therefore, to think that Westminster electoral reform is not on the cards for the foreseeable future, right that the prospects for local PR are higher and right that the hope that STV or something similar might actually be adopted within a decade or so is not unrealistic. Many electoral reform purists will think that the change of focus from the national to the local stage amounts to a severe loss of ambition. But would local electoral reform in itself make a significant difference?

There is no reason to think it would immediately transform such key democratic indicators as electoral turnout or public satisfaction with democracy. Indeed, a recent study has shown that even national electoral reform is unlikely to do that. ${ }^{7}$ On the other hand, it would change the character of local governance. Long-standing one-party fiefdoms are clearly harmful, and STV would greatly weaken them. STV would also require more widespread coalition-building among parties at local level: in Scotland, for example, the number of councils with single-party majority administrations fell from thirteen (out of thirtytwo) to just two in the first STV elections in 2007, though it rose again to six in 2012. Finally, STV would give all significant parties an incentive to organise themselves and campaign even in areas where they do not expect to win most votes. Over time, that might help to rekindle grassroots politics, the benefits of which would gradually percolate through the rest of the political system.

Thus, while changing the local electoral system might seem like a meagre achievement to some diehard electoral reformers, in fact, it would be an important step. 
Major institutional transformations generally happen through the gradual effects of what seemed to many at the time like minor adjustments: the introduction of life peers in 1958 and the creation of departmental select committees in 1979 are perhaps the best examples. The adoption of local STV might well fall into the same category.

\section{Notes}

$1 \mathrm{~N}$. Tyrone and C. Terry, Northern Blues: The Conservative Case for Local Electoral Reform, London, Electoral Reform Society, 2013; L. Baston and W. Brett, Towards One Nation: The Labour Case for Local Electoral Reform, London, Electoral Reform Society, 2014.

2 Alan Renwick, The Politics of Electoral Reform: Changing the Rules of Democracy, Cambridge, Cambridge University Press, 2010; A. Renwick, 'Electoral reform in Europe since 1945', West European Politics, vol. 34, no. 3, 2011, pp. 456-77.

3 Ipsos MORI Political Monitor, January 2014, available at www.ipsos-mori.com, last accessed 1 July 2014.

4 The Coalition: Our Programme for Government, London, Cabinet Office, 2010, p. 27.

5 The Report of the Hansard Society Commission on Electoral Reform (London: Hansard Society, 1976), p. 25.

6 A. C. Cairns, 'The electoral system and the party system in Canada, 1921-1965', Canadian Journal of Political Science, vol. 1, no. 1, 1968, 55-80.

7 S. Bowler and T. Donovan, The Limits of Electoral Reform, Oxford: Oxford University Press, 2013. 